\title{
Assessment of Emotion in Online News based on Kansei Approach for National Security
}

\author{
Noor Afiza Mat Razali ${ }^{1,}$ Nur Atiqah Malizan ${ }^{2,}$ Nor Asiakin Hasbullah ${ }^{3}$ \\ Norul Zahrah Mohd Zainuddin ${ }^{4}$ Normaizeerah Mohd Noor ${ }^{5}$ \\ Faculty of Defence Science and Technology \\ National Defence University of Malaysia \\ Sungai Besi, Kuala Lumpur, Malaysia
}

\author{
Khairul Khalil Ishak ${ }^{6}$ \\ Center for Cybersecurity and Big Data \\ Management and Science University \\ Shah Alam, Selangor, Malaysia
}

\author{
Sazali Sukardi ${ }^{7}$ \\ CyberSecurity Malaysia \\ Selangor \\ Malaysia
}

\begin{abstract}
Securing a nation is more complicated in modern days than how it was decades ago. In the era of big data, massive information is constantly being shared in cyberspace. Online rumours and fake news could evoke negative emotions and disruptive behaviours that possibly can jeopardize national security. Real-time detection and monitoring of unsettling emotions and potential national security threats should be further developed to help authorities manage the situation early. Text in the online news could be weighted with emotions that possibly lead to a misunderstanding that can affect national security and trigger chaos. Thus, understanding the emotion included in the online news and the relationship with national security is crucial. Kansei approach was determined as a methodology capable of interpreting human emotions towards an artefact. This research explores the emotion assessment using Kansei for text in online news and summarized the emotion variable factors that are likely to have a relationship with an individual state of mind towards one of the national security elements which are political security. The result determines that the identified variables of factors were "Frustrated," Consent," Resentful" and "Attentive". This gives an understanding of the significant effect of people's emotions represented in the text for political security elements.
\end{abstract}

Keywords-Online news; kansei; national security; political security

\section{INTRODUCTION}

The increased use of the Internet by the community due to the development and advancement of information technology enables the utilisation of social networks on the digital media platform. According to the statistic of internet user's data by "statista" which is one of the well-known data statistic websites, in the early year of 2021, there are more than 4 billion active internet users across the world. People are connected in cyberspace via various types of existing social networks such as blogs and online news that create massive online data. Online news reports various types of issues that occurred in the country and world near to real-time and may have a potential risk of national security if not being monitored. National security is essential to maintain the survival of the nation and also a critical factor in ensuring national sovereignty through the use of economic power, diplomacy, power projection and political power. Threats related to national security need to be constantly monitored to retain the stability of a country. Moreover, with today's advancement in technology, mass information sharing has become one of the threats to political security.

Political security is one of the most significant elements of national security as it plays a major role in securing the nation's political institution from any threats that can weaken national security. Political institution stability plays a crucial role in sustaining community unity and upholding the rule of law in a country. The necessity for economic development, social harmony and the supremacy of the law is political stability. The rise of political issues can make the political environment unstable and indirectly poses a threat to the state of national security.

Personal convictions based on feelings and sensations are capable of influencing public sentiment than objective evidence [1]. Negative information in the news decreases positive effects due to the influence of negative effects on an emotion such as increased sadness, worries and anxiety [2]. To further understand the relationship between emotion in the text broadcasted in online news, this study proposed the application of the Kansei philosophy approach to evaluate human emotions toward artefacts in form of text gathered from online news. Kansei approach is mainly being utilised in the business and product services domain to obtain users feedback and emotional reaction [3]. However, there is a limited study being done in the national security domain using this approach. This support our research objective which is to assess emotions in national security elements from the online news text, focusing on political security. This study surveys the emotions laid in the online news text by evaluating the sample's reaction towards the text found in the online news. This research will contribute to understanding emotion that exists in online news text and its relationship with political security. 
As for the following sections, it is organized as follows. In the second section, we give a detailed explanation of the background studies. For the next sections, we stated the overview of emotion assessment for online news using the Kansei approach for national security and also discussed the details of the methodology for the assessment of emotion in National Security elements. In Section IV, we present the result and findings of the experiment that had been executed. In the final section, as the conclusion, we summarize the main points of this research paper and discuss the future work plan for this research.

\section{BACKGROUND STUDIES}

\section{A. Security Elements and Political Security}

National security is a very important feature as a protection control for any country [4]. There are several national security dimensions including economic growth and development, the structure of the economic process, welfare of citizens, variability of climatic conditions, preservation of natural resources and political stability [5]. Balzach discussed eight elements of national security which are military security, political security, cybersecurity, human security, homeland security, economic security, environmental security, energy and natural resources security [4]. Meanwhile, other researchers discussed that there are two basic elements in national security, namely, military and non-military. Military security is the competency of a nation to defend itself or intercept military aggression from the outside. The nonmilitary element encompasses political security, cybersecurity, food security, economic security, human security, energy and natural resources security, environmental security, border security and health security [6], [7].

The concept of national security has been explained by emphasising that politics is one of four major national security dimensions [8]. Political security focuses on the stability of institutions and governments. Robert Mandel stated that political security is a concern with the organisational stability of the state's systems of government and the ideologies that give them legitimacy [9]. The role of political security in national security is important since political security acts as a defender in defence of the nation from any form of political oppression that can affect national security. Political oppression can lead to an unvisitable event such as a riot and civil war, which can disturb the unity of people [10]. To avoid these events, there is a need to ensure that the political state is in a stable environment and able to increase the quality of political security.

Political stability becomes a vital interest for national security because there are several threats that come from the political aspect which can harm the nation and weaken the state political security such as violations of the rule of law caused by tensions between communities. Thus, the good stability of the political security can strengthen the national security. A study in India underlined that national security needs to be viewed in political security terms to protect and promote national security goals and objectives [11].

Threats that can shake the country's political security stability are political violence, technology, and political upheaval, which possibly threaten the country's peace. Nowadays, the political issue can be easily expanded in cyberspace because of the sophisticated use of the Internet that can pose a threat to the political atmosphere of the country [12].

\section{B. Online News and Emotions related to National Security Elements (Political Security)}

Digital media such as Twitter and Facebook provide cognitive, affective and behavioural communication platforms that allow individuals to communicate collaboratively [13] and offer news and data mobilisation to individuals and allow them to share their views with many others, enabling them to participate in public engagement [14].

In the field of national security, the study of fear and anger in the political dimension found that these emotions can affect political behaviour and public opinions [15]. The relationship between emotion and the elements of national security can also be seen through human reactions towards environmental security issues. For example, 'hope' is an emotion that is shown by individuals with pro-environmental behaviours in relation to their feelings towards climate change policies [16]. The attachment of emotion can also be found in cybersecurity. Nowadays, cyberspace has become one of the potential threats to the country's national security through the spread of fake news and hate speeches [17], especially when people believe and spread them. This is a concern for national security because it could harm the entire nation [18]. The relationship between emotion and hate speech in cyberspace is undeniable because cyberspace has an emotionally rich nuance and space where people can share their feelings, emotion, and thoughts [19].

A study also shows that national security can be strengthened by monitoring text that is being shared online because in the current online system, information is mostly displayed in text form [20] and words can reveal information like individual preferences, thoughts, emotions, and behaviours. A large amount of textual data has been generated because it is typical for an individual or persona to express emotion in words or text in cyberspace [21].

\section{Kansei Approach}

Kansei is a Japanese term for the sensibility and emotions that individuals have about a product or the environment [22]. Kansei can relate sensitivity, feeling and emotion. A study by Khairul discussed the application of Kansei Engineering in developing the Kansei Information Security Assessment (KISA) for developing a framework for user's emotional assessment in the security domain, which employed the Kansei Engineering methodology in assessing human emotion factors in the designs and implementations of information security policies [23]. Other studies had used the Kansei approach in assessing the concept of trust in the information security domain by analysing the emotion of positive and negative that can influence the concept of trust [24].

Also, another research has been done focusing on user's rage assessment for information security by using Kansei Engineering methodology. The artefacts were utilised as the specimen to evaluate the rage emotion on chatbot [25]. The 
research had shown that the Kansei approach could also be utilised on other applications or research related to the assessment of emotion including the information security domain. This supports the present study in implementing Kansei for political security related emotion assessment.

\section{EMOTION ASSESSMENT FOR ONLINE NEWS USING KANSEI APPROACH FOR NATIONAL SECURITY}

In this work, we proposed that Kansei can be utilised as an approach to measure users' emotion in a text from the online news where the result can show the relationship between emotion and the national security elements. We utilised the KJ Method to determine the KW for the national security domain.

\section{A. Conceptual Model for Relationship between the National Security, Physical Segment and Psychological Segment}

Kansei's most common approach involves an evaluation activity using a pre-defined artefact accompanied by a statistical analysis of data. Kansei approach can evaluate the relation of emotion towards the artefact according to the research objectives. Many traditional methods seek to generalise such sensitivity through an average assessment of subjects. Relationships are formed between the average Kansei judgments and the specimen attributes [26].

The measurement approaches in Kansei are divided into physical and psychological segments. Eight elements of national security discussed by Balzacq are military security, political security, cybersecurity, human security, homeland security, economic security, environmental security, energy and natural resources security [4]. The additional elements discussed by [6], [7] are food security, border security and health security. The elements of national security are defined as the physical segment. The physical segment consists of stimulus in form of artefact. In this research, the artefacts are the sample of text from the online news.

Kansei evaluation is important to obtain users' evaluation in national security. The attribute set is defined as an emotional descriptor or Kansei Word (KW) that is taken from a noun or an adjective. This method has been used in many studies related to the characterisation of human emotions for various purposes of science such as analysis of emotional video material, emotional effects on viral video, digital learning content and retrieval of images [27]. KW is a word that can be used to represent a user's emotions. Generally, the selection of $\mathrm{KW}$ is made based on the literature review, experts' advice and magazine. The use of Kansei Word was follow up in the domain of research [28]. The use of the Kansei approach is to convey the psychological feelings of a product or an environment assembled with it. Fig. 1 shows the conceptual model for the relationship between the national security elements defined by Balzacq, Bahadur and Thakuri and Kshetri with actions stimulated by senses generated by psychological elements. The emotional elements are cited from research by [24] which are emotion, motivation, appraisal and perception.

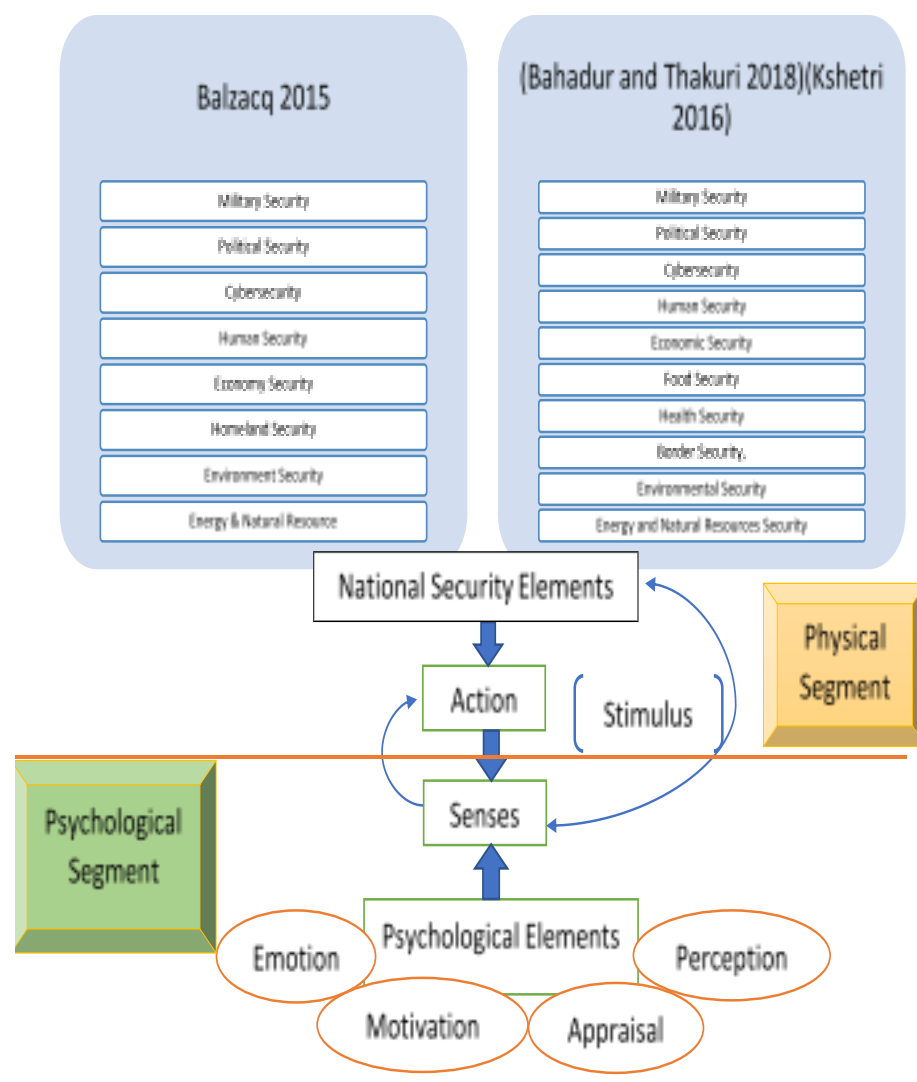

Fig. 1. Conceptual Model for Relationship between National Security Elements, Physical Segment and Psychological Segment.

Human mental states such as behaviour, act, expression and impression, is addressed by the psychological segment that can be measured using self-reporting systems such as the Different Emotional Scale (DES), the Semantic Differential (SD) scale or the free labelling method [25], [29]-[32]. Also, several methods using sensory measures including the SD have been used to determine the accuracy of Kansei objects represented by $\mathrm{KW}$.

\section{B. Emotion Assessment using Kansei}

This section focuses on the related processes in Kansei evaluation measurement that was executed to measure the relationship between the emotion and the text in the online political news. Our focus for this study is political security which is one of the elements of national security. The Kansei evaluation measurements are based on responses gathered using the Kansei Checklist, a form of a questionnaire that includes emotional keywords or known as Kansei Words (KW) [33]. The evaluation was done in four phases. Phase 1 is Instrument Preparation, Phase 2 is the Establishment of Kansei Words (KW), Phase 3 is Kansei Evaluation Procedure and Activity, and Phase 4 is Kansei Result Assessment. The methodology for the assessment of emotion in national security elements focusing on political security used in this research is shown in Fig. 2. 


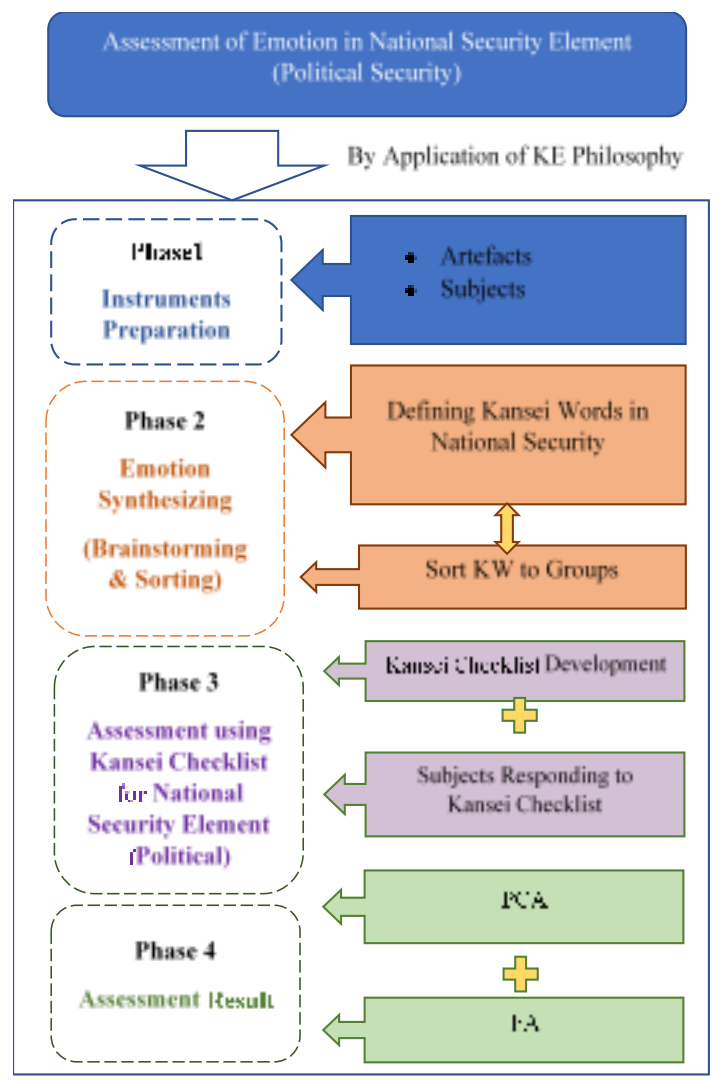

Fig. 2. Methodology for Assessment of Emotion in National Security Elements.

1) Phase 1: Instrument preparation: This step determines the instruments which are the Kansei artefacts and the subjects that will be used in research. Artefacts include the text in the online news that have a relationship with national security elements etc., whereas subjects are people that have an understanding of national security. In this study, the Cadet officers at the National Defence University are our subjects.

2) Phase 2: Establishment of kansei words: Kansei Word $(\mathrm{KW})$ is used for the concept of perception in the chosen product or research domain. The selected Kansei Word should be related and capable of defining the domain for this study. For this study, the focus domain is national security. Significant words in online news that were presumed to give an impact on the state's national security was taken into consideration while establishing the KW[34]. To develop the list of $\mathrm{KW}$ related to national security, the $\mathrm{KJ}$ method, also known as part of the affinity diagram was used. KJ method was founded by Jiro Kawakita as a tool for grouping and summarising emotional keywords into their group preferences [28]. The purpose of the affinity diagram is to assess the group members as they are related to the choice of research domain [35]. The key idea behind the KJ method is to organise ideas. Various methods are used for creative thinking, such as brainwriting, mind maps, and spatial hypertext. $\mathrm{KJ}$ method is a part of the creative thinking methods, which involve brainstorming and structuring the idea [36]-[38]. The KJ method could also be utilised for any mechanism because it is a universal method [39].

Based on the Kansei affinity cluster methodology used by [40] we implemented this phase in three steps which are: i) the initial study step; ii) the exploratory study step, and iii) the KJ application step. The first step was required to emphasise the national security domain as a reference to generate the KW. This phase acquired a common type of results. This is because the key point for the idea is related only to the general idea of the national security domain. It was viable as the first action in this research method. The initial KW would be generated according to the national security domain. The process of synthesising the initial $\mathrm{KW}$ was done by referring to the literature on national security and experts.

The second step required human participants. It utilised the results of the initial set of words from the first step. Experts in national security and psychology were recruited to brainstorm KW for the national security domain. Next, multiple processes, cross-searches, and review of synonyms and antonyms from dictionaries and glossaries were performed to make sure that all possible KW for the national security domain has been gathered during this phase. A literation process was also conducted for this phase until all possible KW have been searched and identified. The second step was conducted with all possible lists of KW.

In the third step, participants were recruited to perform an activity based on the KJ Method. The participants are the Cadet officers at the National Defence University, who have the knowledge and exposure to national security. To start the experiment in a controlled environment, each KW was written down on a piece of card or paper. Each word was displayed on a large surface and arranged in random ways for the participants to sort according to their understanding of the national security concept.

This clustering session required a facilitator that acted as a guide for the participants. The participants were required to search for two words that have a relation with each other and to put the linked words together. Other words that were not related were placed aside. The main priority was for words that have a similar relation. If a word has other aspects of relation, a new group was created and the word was set in that group. This repetitive process was considered done when the participants have finished arranging and putting all words together according to their relationships. Words that did not belong to any group were excluded from these groups and the participants put the word into a new group. Each of these words has its headers.

Once the participants have completed the word grouping, a header was assigned to each group. The participants had to develop a question between participants to create the header for the words that represented the group. This phase was concluded with precise keywords that could help the discussion run smoothly. This session could also begin by creating the header first and then word listing and grouping each word that has a relationship with the existing header. Participants need to discuss and decide on the need to create a super header, where the super header will act as a parent to one header or more. 
Lastly, the participants had manually evaluated the words that have been grouped under each header. Then, they were required to check the final diagram to confirm that the headers and groups were represented according to their right cluster.

3) Phase 3: Kansei evaluation procedure and activity: After determining the KW for national security, Kansei evaluation was conducted using the $\mathrm{KW}$ for national security. For this phase, we choose political security, the elements of national security as the focus of our Kansei Evaluation. To accomplish the objective, the Kansei assessment for this study was carried out with 20 participants selected to took part in the tests. The activity was conducted in two separate sessions. There were 10 people involved in the first session and another 10 people for the second session. For phase 3, a set of stimuli focusing on the political security element was prepared.

a) Stimuli: Stimuli was produced from 30 sample texts from political news from various news platforms in Malaysia. The selection process took the most time and effort to complete before finalising the number of sample texts. There were several steps taken in examining the sample texts. The first step was looking for the digital platform news that is popular among societies in Malaysia, such as "The Star," "New Straits Times," and "Malaysiakini." The second step was searching for news that focuses on the aspects of politics in the chosen news platform. The next steps were to select and examine certain texts in the chosen political news. The text samples were defined in regard to certain control parameters and the prerequisite for matching the domain research. The procedure was repeated for each chosen news platform. The precision of the text sample specimen has to be considered when finalising the text sample. All 30 sample texts were collected since the assessment focused on text features that only require textual material to be displayed and evaluated by the participant. Examples of sample text are shown in Fig. 3.

b) Participants: 20 people were recruited for the evaluation and the experiments were performed in Malaysia. These participants were from the state security field. Participants preferred not to have a visual disability problem and agreed to see textual visualisation that may contain harsh words. Participants comprised 11 men and 9 women aged between 19 and 30 years. Subjects were asked to respond to questioners on the basis of their feelings for each of the text samples displayed in front of them.

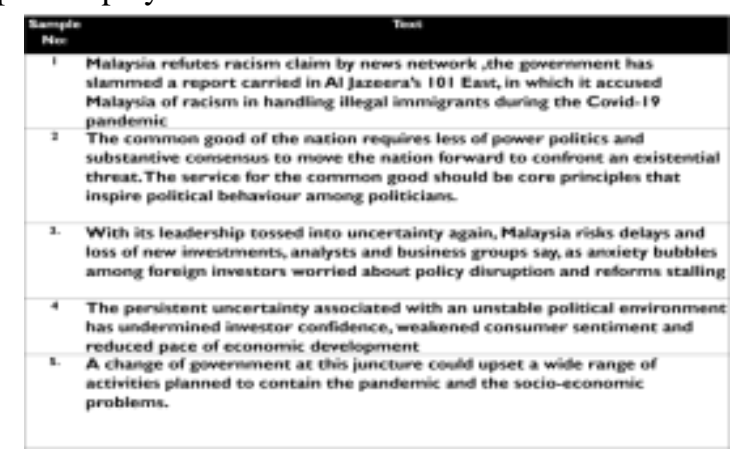

Fig. 3. Examples of Sample Text. c) Procedure: The people who took part in all sessions participated in their own will and were allowed to self-report their emotional reactions on the assessment sheet. The evaluation began with a briefing on consent statements and guidance for the participants. For each of the 30 sample texts, a checklist containing KW adapted from an affinity cluster for national security in political security aspects was added.

Kansei Checklist was created to measure emotions after the KW was defined. Kansei Checklist was represented as a sort of a questionnaire that consists of KW. Fig. 4 shows the sample of Kansei Checklist Evaluation forms containing a checklist of 25 $\mathrm{KW}$ for each sample text that was distributed to all participants to prevent response bias. The order of the Kansei words for each sample text was in a random arrangement.

The participants were asked to complete Kansei word ratings in conjunction with their emotional reactions to the sample text. Participants gave ratings on their feelings after viewing each sample text in the shape of a 5-degree bipolar of semantic differential (SD). The semantic differential method developed by Osgood is a common scaling device for quantifying subjective consumer emotions [41]. The purpose of the semantic differential approach is to provide quantitative support to encourage users to provide an objective assessment of the specimen's psychological value. This involves descriptive scales with adjectives to assess the similarity or difference between subjects. A semantic differential of 5 points was used in this present analysis because these scales appear to be more easily interpreted by respondents than more point score methods. Fig. 4 shows that the Kansei checklist established was arranged in a 5-point semantic differential scale and consisted of $25 \mathrm{KW}$. The rating scale was $(1="$ not at all; "5=" very much"). Each session lasted for 1 hour; before moving to the next sample text, the participant was given 5 minutes to complete the rating, and similar instructions were given for all 30 sample texts.

4) Phase 4: Kansei result assessment: The final phase is the Kansei assessment result discussed in the next chapter.

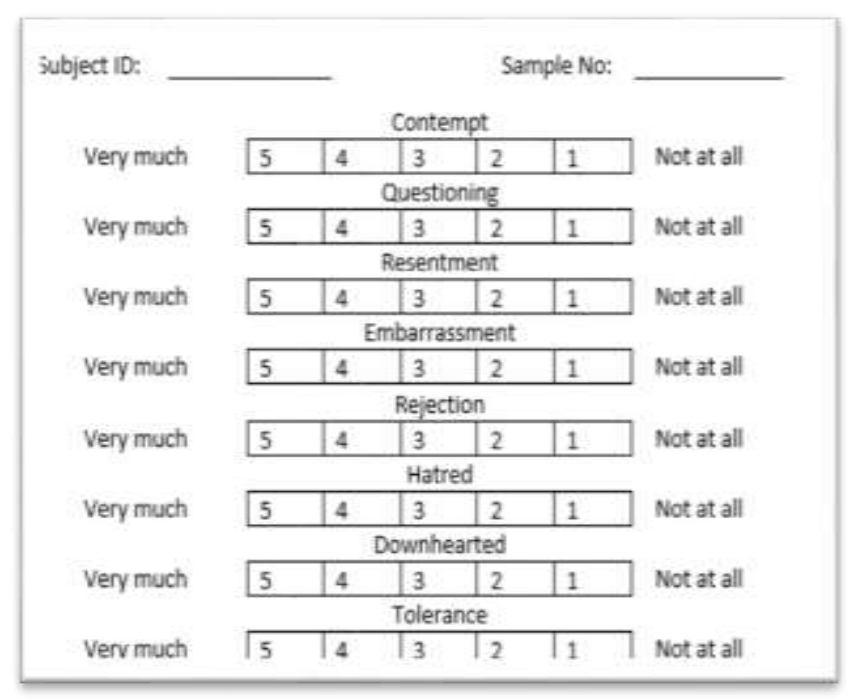

Fig. 4. The Sample of Kansei Checklist. 


\section{RESULT AND FINDINGS}

\section{A. Result on Kansei Affinity Diagram}

Kansei most common approach involves an evaluation activity using a pre-defined artefact accompanied by a statistical analysis of data. Kansei approach can evaluate the relation of emotion towards the artefact according to the research objectives. Many traditional methods seek to generalise such sensitivity through an average assessment of subjects. Relationships are formed between the average Kansei judgments and the specimen attributes [34]. The measurement approaches in Kansei are divided into physical and psychological segments.

Eight elements of national security discussed by Balzacq are military security, political security, cybersecurity, human security, homeland security, economic security, environmental security, energy and natural resources security [4]. The additional elements discussed by [6], [7] are food security, border security and health security. The elements of national security are defined as the physical segment. The physical segment consists of stimulus in form of artefact. In this research, the artefacts are the sample of text from the online news.

The results from the initial study were then used in the exploratory study as a reference for experts to derive more Kansei Words and to perform cross-checks from the glossaries. The number of Kansei Words from the initial study has increased from 41 to 236, which included "embarrassment", "loathing", "apprehension", "appalling", "despair", "woefulness", "horrified", "shock", "relief", and "bitter". Identified Kansei Words is shown in Table I.

After utilizing the $\mathrm{KJ}$ method to organise these KWs into "affinity groups", eleven clusters were created by Cadet's students who participate in this study. The compiled KW in each cluster was developed into a dictionary of emotion based on national security, as shown in Table II. The clusters are political security, economic security, border security, cybersecurity, human security, energy and natural resources security, environmental security, military security, food security, health security and personal security.

TABLE I. IDENTIFIED KANSEI WORDS

\begin{tabular}{|l|l|}
\hline References & Kansei Words (KW) \\
\hline$[42]$ & Trust, Empathy, Hope \\
\hline$[43],[44]$ & Fear \\
\hline$[44]$ & $\begin{array}{l}\text { Anger, Hatred, Contempt, Shame, Guilt, Envy, Love, Care, } \\
\text { Pity, Anxiety }\end{array}$ \\
\hline$[45]$ & $\begin{array}{l}\text { Helplessness, Interest, Sadness, Depression, Disgust, } \\
\text { Worry }\end{array}$ \\
\hline$[46]$ & Doubt \\
\hline$[47]$ & Grief \\
\hline$[48]$ & Alarm, Cautious, Disengaged, Doubtful, Dismissive \\
\hline$[49]$ & $\begin{array}{l}\text { Calmness, Optimism, Tolerance, Prosperity, Ease, } \\
\text { Conformity, Concern, Stiffness, Disquietude, Upset, } \\
\text { Confidence Nervousness, Sympathy, Aggression }\end{array}$ \\
\hline
\end{tabular}

TABLE II. KANSEI AFFINITY CLUSTERS BASED ON NATIONAL SECURITY

\begin{tabular}{|c|c|}
\hline Cluster & Kansei Word \\
\hline Political security & $\begin{array}{l}\text { Contempt, Questioning, Resentful, } \\
\text { Embarrassment, Resentment, Rejection, Hatred, } \\
\text { Downhearted, Disgruntled, Cynical, Anger, } \\
\text { Disbelief, Rejecting, Pissed, Enraged, Fear, } \\
\text { Dejection, Agony, Wrath, Tolerance, Irritated, } \\
\text { Aversion, Eagerness, triumph, contentment, } \\
\text { Satisfaction, Adoration, Affection, Attraction, } \\
\text { Compassion, }\end{array}$ \\
\hline Economic security & $\begin{array}{l}\text { Bargaining, Peeved, Distracted, Interest, } \\
\text { Perplexed, Loathing, Neglect, Impatient, Dislike, } \\
\text { Irritation, Grief, Shaky, Envy, Care, } \\
\text { Disappointment, Scary, Aggravation, Misery, } \\
\text { Insult, Stress, Guilt, Trust, Anxiety }\end{array}$ \\
\hline Border security & $\begin{array}{l}\text { Afraid, Scared, Anguish, Worry, Distrust, } \\
\text { Apprehension, Off Guard, Frightened, Beastly, } \\
\text { Exasperation, Ferocity, Bitterness, Hate, } \\
\text { Apprehensive, Enthusiasm }\end{array}$ \\
\hline Cybersecurity & $\begin{array}{l}\text { Trouble, Insecurity, Anxious, Disturbed, } \\
\text { Astonished, Suspicious, Unsure, Confuse, } \\
\text { Sceptical, Denial, Doubt, Concern, Frustrated, } \\
\text { Appalling, Rage, Spite, Gloom, Disapproving, } \\
\text { Furious, Nervousness }\end{array}$ \\
\hline Human security & $\begin{array}{l}\text { Joyful, Irritable, Dismay, Offended, Love, } \\
\text { Calmness, Upset, Sad, Happy, Optimism, } \\
\text { Humiliation, Ease, Proud, Angry at self, Disgusted } \\
\text { with self, Scornful, Disquietude, Confident, Bold, } \\
\text { Daring, Annoyed, Vengefulness, Jealousy, } \\
\text { Despair, Regret, Nervous, Horrify, Insulted, Irate, } \\
\text { Contentment }\end{array}$ \\
\hline $\begin{array}{l}\text { Energy and natural } \\
\text { resources security }\end{array}$ & $\begin{array}{l}\text { Depression, Distress, Empathy, Blue, Disgust, } \\
\text { Torment, Devastating, Jittery, Blameworthy, } \\
\text { Conformity, Mortification, Annoyance, Revulsion, } \\
\text { Isolation, Mad, Woefulness }\end{array}$ \\
\hline $\begin{array}{l}\text { Environmental } \\
\text { security }\end{array}$ & $\begin{array}{l}\text { Alarm, Concerned, Cautious, Disengaged, } \\
\text { Doubtful, Dismissive, Helplessness, } \\
\text { Uncomfortable, Hope, Hurt, Sadness, Horrified }\end{array}$ \\
\hline Military Security & $\begin{array}{l}\text { Hostility, Terror, Chaotic, Goosebumps, Suffering, } \\
\text { Pride, Terrify, Strong, Hostile, Stiffness, Petrified, } \\
\text { Shock, Fury, Defeat, Serenity, On Edge, } \\
\text { Alienation, Mistrust, Aggravated, Vengeful, } \\
\text { Gloomy, Panic, Grieve, Amazed, Astonished, } \\
\text { Thrill, Exhilaration }\end{array}$ \\
\hline Food Security & $\begin{array}{l}\text { Relief, Unhappy, Vindictive, Depressed, } \\
\text { Unhappiness, Outrage, Dread, Desperate, } \\
\text { Melancholy, Grouchiness, Grumpiness, } \\
\text { Desolation, Satisfaction, Pleasure }\end{array}$ \\
\hline Health Security & $\begin{array}{l}\text { Pity, Displeasure, Lost, Prosperity, Confidence, } \\
\text { Delighted, Hopeless, Excitement, Disappointed, } \\
\text { Compassion, Amusement, Reluctant, Grouchy, } \\
\text { Disdain, Hesitant, Agitated, Edgy, Nauseated, } \\
\text { Tenderness, }\end{array}$ \\
\hline Personal security & $\begin{array}{l}\text { Fearless, Infuriated, Safety, Surprise, Moody, } \\
\text { Lonely, Contrary, Bitter, Shame, Cold Feet, } \\
\text { Loneliness, Hysteria, Horror, Satisfaction, } \\
\text { Inhibited, Sorrow, Remorse, Relaxed, Cheerful, } \\
\text { Guilty, Ashamed, Hopelessness, Miserable, } \\
\text { Dissatisfied with self, Alone, Timid, } \\
\text { Sentimentality }\end{array}$ \\
\hline
\end{tabular}

From the result in Table II, we found out that $25 \mathrm{KW}$ were clustered and listed in the affinity cluster of keywords under the political security aspects. The KW for political security included "fear, compassion, contempt, disbelief," which describe the political perception and emotions of people based on political security aspects of national security. The results from this procedure are shown in Fig. 5. 


\begin{tabular}{|l|l|l|l|l|}
\hline Contempt & Resentment & Questioning & Embarrassment & Rejection \\
\hline Hatred & Downhearted & Disgruntled & Cynical & Anger \\
\hline Disbelief & Enraged & Fear & Wrath & Agony \\
\hline Tolerance & Irritated & Aversion & Eagerness & Triumph \\
\hline Contentment & Satisfaction & Adoration & Attraction & Compassion \\
\hline
\end{tabular}

Fig. 5. Kansei Words for Political Security Element.

\section{B. Result from the Kansei Assessment}

This sub-section discusses the analysis performed over the result obtained from the experiment. First, the validity of the test was validated by the Cronbach Alpha reliability test. Next, the correlation of the Kansei words towards the sample text was analysed. The result was analysed using PCA and FA. PCA and FA is a statistical method that is able to construct a well-organised Kansei space with the selected Kansei words for specific purposes. The statistical analysis that comes from PCA and FA can give clear explanations and visual output. It also contains a descriptive graph that is easy to be analysed and understood. It also directly translates numerical data into useful information. For example, radar plots and profiles for Kansei words can be used to check similarities among words.

PCA is an abbreviation from the word Principal Component Analysis (PCA). It is a commonly used multivariate technique that helps to understand the underlying data structure. This method in the preference matrix was resolved into a set orthogonal preference dimension represented both Kansei words and artefact. The KWs were represented in the first two principal components, giving a visual representation of the semantic space. The located Kansei words (the responses) was shown on a scatterplot with the first principal components displaying similarly perceived responses.

Factor Analysis or abbreviated as FA, is helpful to direct the process of concept mapping by clustering the Kansei Words into smaller groups. FA is a technique of statistical data reduction used to observe the variability of correlations in random variables or minor differences in random variables that are then compared. This reduction is important as the level of any attribute is influenced by the effects of other attributes. Usually, FA may reduce the data level of different attributes to some important degrees. Inductive analysis can be done through factor analysis. The outcome is evaluated by measuring a coefficient of correlation between each variable and another variable. The FA is often used to analyse Kansei's study concept and psychological structure due to the data structure generated from the data collection.

In this research, reliability analysis was performed to expose the reliability and efficacy of the Kansei Checklist survey questionnaire. A high-reliability coefficient value means that the Kansei Checklist survey questionnaire is reliable. The accuracy of the results from the survey carried out over various lengths was evaluated. To test internal accuracy, the Cronbach alpha of the Kansei Checklist was determined. Cronbach's alpha is the statistic commonly used today to estimate internal consistency. It explains that alpha is maximised when each item on a scale shares a common variance with at least some other items on the scale [50]. Several reports suggested that the benchmark value for
Cronbach's alpha of 0.70 above is acceptable; nevertheless, 0.80 or higher is preferred.

Based on Fig. 6, this study yielded a Cronbach's total alpha value of 0.969 , which is greater than the 0.7 typical benchmark value. The reliability of the Kansei checklist was verified by this.

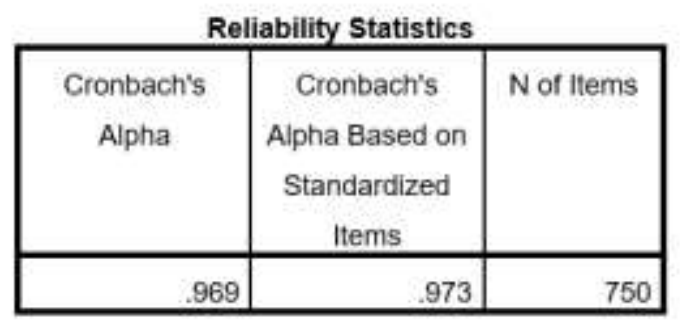

Fig. 6. Reliability Analysis.

This research focused on the impact of the emotion in the text on political news. Thus, for this research, the evaluation was done by PC loading because it can help in representing the evaluation between the Kansei words and specimen; first, the visibility of distributed emotions across the semantic space is studied to deliver an indication that the assessment of emotions is effective. Effective evaluation is needed to explain the importance of the data on emotion to further evaluate operations. It can be shown from Fig. 7 that there was a decent distribution of $\mathrm{KW}$ on both axes, suggesting an efficient evaluation of emotion. After that, the emotional structure axes were observed.

The plot reveals the emotions that generated large negative loads of the first PC (x-axis), which were led by 'Satisfaction.' The field on the left side of the chart corresponded to those emotions. On the other side, emotions generated by large positive PC loads were "Rejection," "Embarrassment" and "Downhearted." Also, the dense section at the most right of the semantic space was presented by them. Then, this axis was named as the 'Emotional' axis. From there, it can predict those variables with high score values on this component, which have a higher sense of emotion.

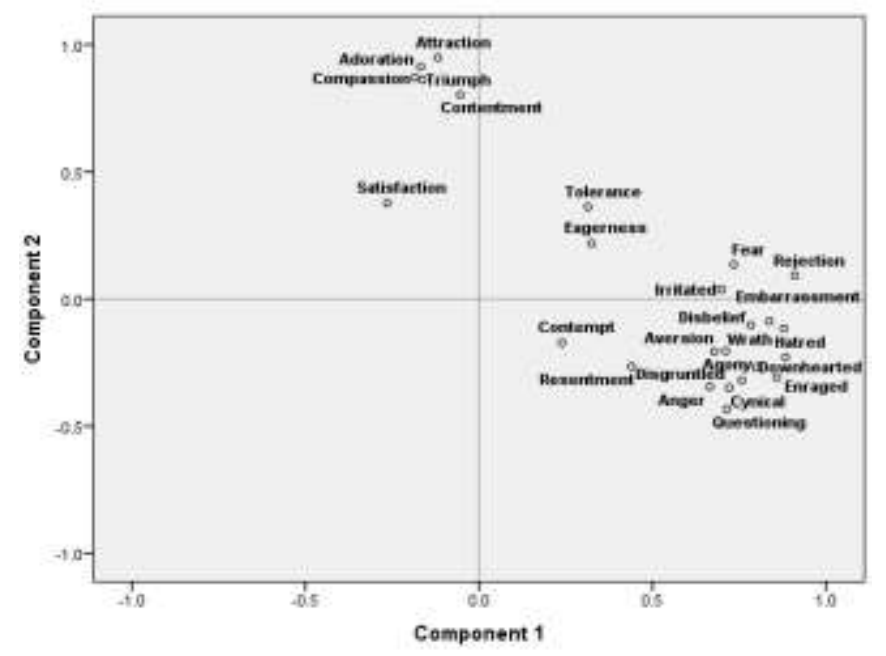

Fig. 7. Result of PC Loading. 
For the second component loading (y-axis), emotions that have larger positive loading were "Attraction" and "Adoration". The emotions on the side larger negative loadings were "Questioning," "Anger," and "Cynical." The research identified this PC as the 'Acceptance' axis. Low-score factors in this component were more toward having high acceptance characteristics and vice versa.

FA was used to recognise important Kansei factors for the emotion of sample texts in political news that could affect the unity of people and state national security. FA is widely used to extract the psychological structure of the emotional component that constitutes the fundamental principle of the study domain [51]. Based on statistical data, FA demonstrates a reduction technique to explain variability among observed random variables in terms of unobserved random variables called factors. To reduce the number of complex variables and enhancement the interpretation of variables, FA was performed by the Varimax rotation. This was accomplished by analysing the contribution of variables after the rotation of varimax. Kaiser introduced the Varimax rotation in 1958, which then became the most common rotation approach for simplifying the understanding of variables [52]. This research used the average assessment value between specimens to find the factors. Table III summarises the contributory variable outcomes.

TABLE III. FACTOR ANALYSIS RESULT

\begin{tabular}{|c|c|c|}
\hline \multirow{2}{*}{ Factor } & \multicolumn{2}{|c|}{ Contribution and Accumulated Contribution } \\
\cline { 2 - 3 } & Contribution (\%) & Accumulated contribution \\
\hline 1 & 38.920 & 38.920 \\
\hline 2 & 20.760 & 59.680 \\
\hline 3 & 19.029 & 78.709 \\
\hline 4 & 7.299 & 86.008 \\
\hline
\end{tabular}

Table III shows that the first factor explains $38.920 \%$ of the result, which represents the majority of the key factor contribution and has a significant impact on Kansei words. $20.760 \%$ of the data were explained by the second factor, while the third factors have a small factor contribution of the $19.029 \%$ and the fourth factor has a small percentage contribution of $15.09 \%$. The first factor alone constituted $38.920 \%$ of variability, while the second variable described $60.759 \%$ of the variability.

The inclusion of the second factor was assumed considerable; thus, much of the data may be clarified by the first two factors. Whereas Factor 3 and Factor 4 contributed $78.709 \%$ and $86.008 \%$, correspondingly. Slight segments of the third factor and the fourth factor were considered to be significant since they can be summed as the contribution rate that represents all the data results. The results of factor loading in ascending order are shown in the following Table IV. The result classified a big value of variables into groups. This data needs to be analysed to help to clarify the emotional connection towards the sample texts. Variables with a higher score are considered important factors.
TABLE IV. THE FACTOR LOADING OF THE 25 VARIABLES USING FOUR FACTORS

\begin{tabular}{|c|c|c|c|c|}
\hline \multirow{2}{*}{$\begin{array}{l}\text { Variables/ } \\
\text { Adjectives }\end{array}$} & \multicolumn{4}{|c|}{ Factors } \\
\hline & Factor 1 & Factor 2 & Factor 3 & Factor 4 \\
\hline Rejection & 0.910 & & & \\
\hline Hatred & 0.883 & & & \\
\hline Embarrassment & 0.878 & & & \\
\hline Enraged & 0.858 & & & \\
\hline Disbelief & 0.837 & & & . \\
\hline Downhearted & 0.798 & & & \\
\hline Wrath & 0.783 & & & . \\
\hline Agony & 0.757 & & & \\
\hline Fear & 0.734 & & & \\
\hline Cynical & 0.721 & & & \\
\hline Questioning & 0.713 & & & \\
\hline Disgruntled & 0.710 & & & \\
\hline Irritated & 0.699 & & & \\
\hline Aversion & 0.678 & & & \\
\hline Anger & 0.665 & & & \\
\hline Attraction & & 0.948 & & \\
\hline Adoration & & 0.913 & & \\
\hline Compassion & & 0.870 & & \\
\hline Triumph & & 0.862 & & \\
\hline Contentment & & 0.802 & & \\
\hline Contempt & & & 0.880 & \\
\hline Resentment & & & 0.810 & \\
\hline Satisfaction & & & -0.649 & \\
\hline Tolerance & & & & 0.796 \\
\hline Eagerness & & & & -0.680 \\
\hline
\end{tabular}

The structure of $\mathrm{KW}$ can be seen and observed in the analysed findings of this research. This research defined the value of 0.7 as average. However, a slightly lower score can also be known as a substantial concept [53]. From Table IV above, it is clear that the significant factors for a sample text in political news specimens were defined by 4 factors. The list of content in the first factor included "Rejection," "Hatred," "Embarrassment," "Enraged," "Disbelief," "Downhearted," "Wrath," "Agony," "Fear," "Cynical," "Questioning," "Disgruntled," "Irritate," "Aversion," and "Anger." This research labelled this Kansei space as "Frustrated." The second factor consists of "Attraction," "Adoration," "Compassion," "Triumph," and "Contentment." This research labelled this Kansei space as "Consent." The third factor included "Contempt," "Resentment," and "Satisfaction." This Kansei space was labelled as "Resentful." 
After that, the fourth factor involved "Tolerance" and "Eagerness." This research labelled this Kansei space as "Attentive." When labelling all the factors or deciding the term for Kansei space, this research followed the standard practice in Kansei of choosing representative terms that one would believe and effectively characterise the group of factors or Kansei space. There was no conditional decision for this since there was no correct or incorrect judgment of the chosen keywords. As long the chosen keywords can be parameters that match the variable of the group factors.

These four variables together accounted for $86.008 \%$ of the total results. The outcome result from the FA proof that the Kansei concept for sample texts from political news was structured by four factors. The four factors were "Frustrated," Consent," Resentful," and "Attentive."

The first two factors with more than $59.680 \%$ of data variance are important concepts for texts in political news emotional concepts. The result indicates that Factor 1 was the most important Kansei concept for text in political news since it consists more than the percentage value of data variance that influences the result. Meanwhile, Factor 2 contained fewer correlations than Factor 1 but could be defined as potential variables against the factor.

The insertion of the third and fourth factors tended to be significant, even if the contribution was lower for these two factors, which was $19.029 \%$ and $7.299 \%$. This research agreed to preserve the third and fourth factors because of the importance of the KWs toward the sample text specimens. These two factors could be adding as an important concept of text in political news, which could be used as supporting factors for the main factors above described by the first and second factors. Although the first and second variables may have been concluded as major significant Kansei concepts, other factors should be used to support the comprehension of the emotion towards the political news that could impact the people and state national security.

It can be observed from the above results that the text in political news influences people's emotions. The sample texts in political online news used as an artefact for this research produced emotional feedback and most likely toward negative views. From the data analysis, it can be understood that the type of word in the text has a significant influence on a particular emotion. This research managed to conclude four labels of emotions that have a significant relationship with political security elements in the national security domain.

\section{CONCLUSIONS}

This research explored the utilization of Kansei approach as a methodology to assess texts in online news that touch on national security issues and try to understand the relationship between the text and emotion that may affect the political stability in national security. This study has therefore adopted the KJ method in finding the KWs emotion words for national security to test the emotional response toward the subjects.

This research has shown four important factors that established Kansei's basic concepts for text in political security elements that could impact the state national security. "Frustrated," Consent," Resentful" and "Attentive" were the identified variables of factors. Consequently, these four variables were likely to give a high level of political understanding, awareness and effect on the individual's state of mind in regard to the political issues. This analysis selected text on various news platforms including "the Star" and "News Strait Times" online newspaper. This research selected texts on political issues with the text viewing and reading experience; the subjects reacted to it with mixed opinions that consisted of negative and positive reactions.

\section{DiscuSSION AND FUTURE WORK}

This research is an ongoing study that shows the pilot result regarding people's emotions extracted from text in political online news. Emotions of human beings are influenced by what they see and depends on how the eyes and brain are functioning together to generate the reaction. The results of this study can be utilised as a foundation to understand the relationship between emotion and political knowledge from textual representations in digital media. Our next step is to perform activities with a larger group of participants to obtain more comprehensive data for the analysis. The process of evaluating the respondents' results needs to be carefully managed especially during the process of entering the data into the data analysis software. It is to prevent the unmatching and wrong results. Other than that, the limitation of this study is the result was only referred to the emotion words in the text without specific emotion weight value being determined. Given the importance of the weight score for each word in opinion mining, the mechanism to determine the weight score is also essential, thus, an extended study can be done to identify and analyse the method that can be implemented to measure the weight of the emotion word that is related to national security. Furthermore, a detailed analysis including a thorough assessment and evaluation of emotion is required for expanding the research outcomes. The results also can be utilised to establish national security dictionary that can be utilised for opinion mining.

For future work, we are planning to investigate and observe people emotions in the text that are being published on other digital platforms such as social media by using the Kansei approach. The research will help to understand more areas on national security elements in cyberspace with any type of digital platform. Also, potential future research will be the adoption of automation of Kansei approach using machine learning technique for the development of dictionary for national security domain to be used in opinion mining.

\section{ACKNOWLEDGMENTS}

The authors would like to thank all experts and participants for their precious contribution in provided their insight and expertise that greatly assisted towards the whole research activities. This research is fully supported by the National Defence University of Malaysia (UPNM) under Short Grant UPNM/2020/GPJP/ICT/5. The authors fully acknowledged UPNM and the Ministry of Higher Education Malaysia (MOHE) for the approved fund, which makes this research viable and effective. 


\section{REFERENCES}

[1] L. Bode and E. K. Vraga, "In Related News, That Was Wrong: The Correction of Misinformation Through Related Stories Functionality in Social Media," vol. 65, pp. 619-638, 2015, doi: 10.1111/jcom.12166.

[2] N. De Hoog, "Is the news making us unhappy? The influence of daily news exposure on emotional states," pp. 157-173, 2020, doi: 10.1111/bjop.12389.

[3] Z. Li, Z. G. Tian, J. W. Wang, and W. M. Wang, "Extraction of affective responses from customer reviews: an opinion mining and machine learning approach,” Int. J. Comput. Integr. Manuf., vol. 33, no. 7, pp. 670-685, 2020, doi: 10.1080/0951192X.2019.1571240.

[4] T. Balzacq, "What is national security?," What is Natl. Secur., vol. 52, no. 4, pp. 33-50, 2015, doi: 10.3917/ris.052.0033.

[5] J. and A. B. Scheffran, "Climate and conflicts: The security risks of global warming," Reg. Environ. Chang., vol. 11, pp. 27-239, 2011, doi: 10.1007/s10113-010-0175-8.

[6] B. Bahadur and S. Thakuri, "Human Security : Concept, Dimensions \& Challenges Running Head : Human Security Human Security : Concept, Dimension And Challenges An Article Submitted to Lt . Gen . ( Retd .) Balananda Sharma For the Partial Fulfillment of the Internal Evaluation of th," no. April, 2018.

[7] N. Kshetri, "The quest to cyber superiority: Cybersecurity regulations, frameworks, and strategies of major economies," Quest to Cyber Super. Cybersecurity Regul. Fram. Strateg. Major Econ., pp. 1-240, 2016, doi: 10.1007/978-3-319-40554-4.

[8] R. Vxyrnen, "Conceptual Analysis by Robert Mandel BOOK REVIEWS Concepts of Security Revisited," no. May, 2014.

[9] B. Buzan, "New Patterns of Global Security in the Twenty-First Century," Int. Aff. (Royal Inst. Int. Aff. 1944-), vol. 67, no. 3, pp. 431451, 1991.

[10] L. Ronken, H. Eilers, and G. Re, "Strike , Riot and Civil Commotion An Increasingly Significant Form of Cover," no. September, 2020.

[11] D. Enclave, R. Tula, and R. Marg, Institute for Defence Studies and Analyses (IDSA), no. 1. 2019.

[12] R. Sandoval-almazan and J. R. Gil-garcia, "Towards cyberactivism 2 . 0 ? Understanding the use of social media and other information technologies for political activism and social movements," vol. 31, pp. 365-378, 2014.

[13] B. D. Loader and D. Mercea, "Information, Communication \& Society NETWORKING DEMOCRACY?,” 2011, doi: 10.1080/1369118X.2011.592648.

[14] S. Klar, "How Partisan Online Environments Shape Communication with Political Outgroups," vol. 13, pp. 2287-2313, 2019.

[15] T. G. Coan, J. L. Merolla, and E. J. Zechmeister, "Emotional Responses to Human Security Threats : Evidence from a National Experiment," pp. 1-26, 2012.

[16] I. Lorenzoni, S. Nicholson-Cole, and L. Whitmarsh, "Barriers perceived to engaging with climate change among the UK public and their policy implications," Glob. Environ. Chang., vol. 17, no. 3-4, pp. 445-459, 2007, doi: 10.1016/j.gloenvcha.2007.01.004.

[17] G. Belova and G. Georgieva, "Fake News as a Threat to National Security," Int. Conf. KNOWLEDGE-BASED Organ., vol. 24, no. 1, pp. 19-22, 2018, doi: 10.1515/kbo-2018-0002.

[18] E. Relations, "Cybersecurity: A National Security Issue ?," pp. 1-7, 2018.

[19] M. Yassine and H. Hajj, "A framework for emotion mining from text in online social networks," Proc. - IEEE Int. Conf. Data Mining, ICDM, pp. 1136-1142, 2010, doi: 10.1109/ICDMW.2010.75.

[20] C. Smeureanu, I., \& Bucur, “Applying Supervised Opinion Mining Techniques on Online User Reviews," Inform. Econ. J., vol. 16, no. 2, pp. 81-91, 2012.

[21] A. F. Ab Nasir et al., "Text-based emotion prediction system using machine learning approach,” IOP Conf. Ser. Mater. Sci. Eng., vol. 769, no. 1, 2020, doi: 10.1088/1757-899X/769/1/012022.

[22] P. Lévy and T. Yamanaka, "Towards a definition of Kansei TOWARDS A DEFINITION OF KANSEI,” no. May, pp. 1-4, 2014.
[23] K. K. Ishak, N. A. M. Razali, A. M. Lokman, and K. Toshiyuki, "Kansei Information Security Assessment (KISA): Characterizing Trust as Stimuli for User Emotional Assessment in Information Security," Indian J. Sci. Technol., vol. 9, no. S1, pp. 1-6, 2016, doi: 10.17485/ijst/2016/v9is1/106846.

[24] A. Noor and K. K. Ishak, "The Assessment of Trust in Information Security Using Kansei," vol. 1, pp. 194-202, 2020, doi: 10.1007/978981-15-7801-4.

[25] N. A. M. Razali, K. K. Ishak, N. J. A. MdSaad, N. M. Zainudin, N. A. Hasbullah, and M. F. M. Amran, "Conceptualization of Use as Rage Assessment Using Chatbot Interface by Implementing Kansei Engineering Methodology for Information Security," in Proceedings of the 8th International Conference on Kansei Engineering and Emotion Research, 2020, pp. 184-193.

[26] A. M. Lokman and M. Nagamachi, Kansei Engineering: A Beginners Perspective. University Pub. Centre (UPENA), 2010.

[27] R. E. Guadagno, D. M. Rempala, S. Murphy, and B. M. Okdie, "What makes a video go viral? An analysis of emotional contagion and Internet memes," Comput. Hum. Behav., vol. 29, no. 6, p. $23122319,2013$.

[28] S. T. W. Schütte, J. Eklund, J. R. C. Axelsson, and M. Nagamachi, "Concepts, methods and tools in kansei engineering," Theor. Issues Ergon. Sci., vol. 5, no. 3, pp. 214-231, 2004, doi: 10.1080/1463922021000049980.

[29] J. Schütte, S., Schütte, R., Eklund, "Affective Values of Lift Trucks - an Application of Kansei Engineering," 2005.

[30] M. Ishihara, K., Nakagawa, R., Ishihara, S., Nagamachi, “An ECommerce Site to Propose Gift Flower Arrangements That Fit Kansei and Social Manners.," 2007.

[31] M. Lokman, A.M., Noor, N. M., Nagamachi, "ExpertKanseiWeb - A Tool To Design Kansei Website," 2009.

[32] Y. Hashizume, A., Masaaki, K., Toshimasa, "Relative Importance of Design and Usability of Cell Phone in Terms of Age and Gender.," 2010 .

[33] A. Hadiana, "Analysis Learners ' Preference in E-Learning System Using Kansei Kansei Approach Using Approach,” Trends in E-learning, 2018, doi: 10.5772/intechopen.75620.

[34] A. M. Lokman and K. A. Kamaruddin, "Kansei affinity cluster for affective product design," Proc. - 2010 Int. Conf. User Sci. Eng. i-USEr 2010, no. January 2015, pp. 38-43, 2010, doi: 10.1109/IUSER.2010.5716719.

[35] J. Pitaktiratham, T. Sinlan, P. Anuntavoranich, and S. Sinthupinyo, "Application of Kansei Engineering and Association Rules Mining in Product Design," World Acad. Sci., Eng., Tech., vol. 69, no. 9, pp. 198203, 2012.

[36] U. Neupane, K. Nishimoto, M. Miura, and S. Kunifuji, "Random display of hints and its effect on generating ideas in brain-writing groupware," Lect. Notes Comput. Sci. (including Subser. Lect. Notes Artif. Intell. Lect. Notes Bioinformatics), vol. 5178 LNAI, no. PART 2, pp. 863-870, 2008, doi: 10.1007/978-3-540-85565-1-107.

[37] T. Buzan, The ultimate book of mind maps: unlock your creativity, boost your memory, change your life. London: HarperThorsons, 2006.

[38] C. C. Marshall and F. M. Shipman, "Spatial Hypertext: Designing for Change," Commun. ACM, vol. 38, no. 8, pp. 88-97, 1995, doi: 10.1145/208344.208350.

[39] R. Scupin, "The KJ method: A technique for analyzing data derived from Japanese ethnology," Hum. Organ., vol. 56, no. 2, pp. 233-237, 1997, doi: 10.17730/humo.56.2.x335923511444655.

[40] N. J. A. M. Saad et al., "Kansei Engineering Approach for Measuring Political Propaganda: A Case of Malaysia,” Int. J. Eng. \&amp; Technol. Vol 7, No 4.29 Spec. Issue 29DO - 10.14419/ijet.v7i4.29.21838, vol. 7, no. November, pp. 31-35, 2018, [Online]. Available: https://www.sciencepubco.com/index.php/ijet/article/view/21838.

[41] P. H. Osgood, Charles E.; Suci, George J.; and Tannenbaum, The Measurement of Meaning. Urbana. Illinois: University of Illinois Press, 1957.

[42] T. A. Myers, M. C. Nisbet, E. W. Maibach, and A. A. Leiserowitz, "A public health frame arouses hopeful emotions about climate change: A 
Letter," Clim. Change, vol. 113, no. 3-4, pp. 1105-1112, 2012, doi: 10.1007/s10584-012-0513-6.

[43] J. S. Lerner, "Improving national security through research on emotion and decision making," pp. 1-3, 2016.

[44] A. Crawford and S. Hutchinson, "Mapping the contours of "everyday security': Time, space and emotion," Br. J. Criminol., vol. 56, no. 6, pp. 1184-1202, 2016, doi: 10.1093/bjc/azv121.

[45] N. Smith and A. Leiserowitz, "The role of emotion in global warming policy support and opposition," Risk Anal., vol. 34, no. 5, pp. 937-948, 2014, doi: 10.1111/risa.12140.

[46] J. Hesterman, "The Emotional Traps of Soft Target Security," ASIS International. .

[47] L. Retter, E. Frinking, S. Hoorens, A. Lynch, F. Nederveen, and W. Phillips, "Relationship between the economy and national security security policy in the Netherlands," 2020.
[48] E. Asekun-Olarinmoye et al., "Public perception of climate change and its impact on health and environment in rural southwestern Nigeria," Res. Rep. Trop. Med., no. August 2015, p. 1, 2014, doi: 10.2147/rrtm.s53984.

[49] O. Zotova, "Emotional Security of People," J. Sib. Fed. Univ. Humanit. Soc. Sci., vol. 8, no. 9, pp. 1816-1833, 2015, doi: 10.17516/1997-13702015-8-9-1816-1833.

[50] K. S. Taber, "The Use of Cronbach' s Alpha When Developing and Reporting Research Instruments in Science Education," 2016, doi: 10.1007/s11165-016-9602-2.

[51] A. M. Lokman, "KE as affective design methodology," pp. 7-13, 2013.

[52] H. F. Kaiser, "The Varimax Criterion for Analytic Rotation in Factor Analysis," no. 3, 1958.

[53] D. Passig, "The Interaction between Gender, Age , and Multimedia Interface Design," pp. 241-250, 2001. 